\title{
The Collapse of Culverts-Arch in Several Cities around the World, Technical Arguments for Their Maintenance and a Legal Proposal for Prohibiting Their Construction in Mexico
}

\author{
Martín D. Mundo Molina*, José L. Pérez Díaz, Daniel Hernández Cruz, Eber Godínez Domínguez \\ Academic Group Science and Engineering, Research Center of the Engineering Faculty, Chiapas State University, \\ Chiapas, Mexico. \\ Email: *ic_ingenieros@yahoo.com.mx
}

How to cite this paper: Molina, M.D.M., Díaz, J.L.P., Cruz, D.H. and Domínguez, E.G. (2019) The Collapse of Culverts-Arch in Several Cities around the World, Technical Arguments for Their Maintenance and a Legal Proposal for Prohibiting Their Construction in Mexico. Journal of Water Resource and Protection, 11, 1489-1502. https://doi.org/10.4236/jwarp.2019.1112087

Received: November 2, 2019

Accepted: December 20, 2019

Published: December 23, 2019

Copyright (c) 2019 by author(s) and Scientific Research Publishing Inc. This work is licensed under the Creative Commons Attribution International License (CC BY 4.0).

http://creativecommons.org/licenses/by/4.0/

\begin{abstract}
Construction underground pipes and underground culverts-arch (UCA) in order to transport the flow natural rivers and city's sewage at the same time, is a practice that should be prohibited by the Mexico National Water Law (NWL). When UCA collapse, it causes severe damage to surrounding infrastructure, public and private property, and puts citizens' lives at risk. This work presents some examples of UCA collapse incidents in several cities around the world, emphasizes how important preventive maintenance of these structures is, highlights the need to classify risk areas, and stresses the need to formulate norms and civil defense plans as article 83 of the NWL suggests. We also propose an addition to Fraction I, article 100 of the National Water Law, to protect the animal and plant life of its banks and safety of their natural runoff.
\end{abstract}

Keywords

Culvert, National Water Law, Collapse

\section{Introduction}

A culvert is a structure that allows water to flow under a road, railroad, trail, or under a street in a city. Culverts come in many sizes and shapes including round, elliptical, flat-bottomed, open-bottomed, pear-shaped, and arch (culvert-arch). The most typical culverts shape of high flow rates, constructed over the small rivers and stream in the majority of cities from Mexico is the arch: stone arch, brick arch and concrete arch. Nevertheless, arch-like civil engineering structures 
have a 6000-year-old history, and it's most likely that the first ones were built in Mesopotamia or Egypt [1]. This constructive heritage passed on to the Greek culture, which used it in the construction of housing, palaces, and temples. However, it was the Romans who perfected the engineering of domes and arch, as we can appreciate in buildings like the Roman Forum, the Pantheon and the aqueducts. When the Romans invaded the Iberian Peninsula, they took this technology to Spain and built Catholic churches and built aqueducts. Eventually, the Spanish inherited this knowledge to the people of the New World, especially Mexico and Peru, and the people used it to build the great chapels of Latin America used it (almost all of them have domes and arch). In Mexico, the cultural heritage from the Spanish remains in the architecture of chapels and aqueducts. The cities of Morelia and Queretaro have two of the most beautiful and antique aqueducts in Latin America, which carried water from the mountains to the city.

Thus, for its structural safety and ease in the construction process, Mexico began using arch structures to build UCA. These large underground drain systems are known as culvert-arch, made of stone, brick or concrete masonry. The first ones were built in Mexico from 1850 to 1900, over the rivers that crossed the historic center of Zacatecas.

After the revolutionary period in 1910, the mestizo bases were laid to build in the Valley of Mexico the political center of the country, the city underwent explosive growth and began using rivers as sewers. For example, the urban zone of Polanco started to dump wastewater into two important rivers of Mexico City in 1928.

The post-revolutionary idea of constructing an underground culvert pipe and UCA in order to transport the flow natural rivers and city's sewage at the same time became popular and replicated throughout the country. After a great flood that affected Valle de Mexico in 1950, Mexico City's government decided to bury the Mixcoac, Churubusco, La Piedad, and Consulado rivers into a high-flow culvert.

The rivers of Mexico Valley and the main provinces of the country were buried for different reasons: for urban expansion, to avoid foul smell produced by wastewater, to "protect cities against river overflows and floods" among others. None of these arguments have a technical backup or any justification from the environmental, hydrological and hydraulic point of view, rather these structures are danger points for the citizens when we consider the risks associated with them. When an extraordinary increase of water levels occur, these structures transport high water flow combined with trash, tree trunks, tree branches, and stone that move at great speed, damage the UCA foundation or cause blockages. Unfortunately, the cities expanded above the UCA, resulting in many buildings and houses that today stand over the rivers buried, a situation that puts thousands of people living in the federal limits of rivers and streams at great risk.

For these reasons, the main objectives of this research are: 1) show some examples of UCA collapse incidents in several cities around the world; 2) emphasize how important preventive maintenance of these structures; 3) highlight the 
need to classify risk areas, and stress the need to formulate norms and civil defense plans as article 83 of the NWL suggestions and 4) propose an addition to Fraction I, article 100 of the National Water Law, to protect the animal and plant life of its banks and safety of their natural runoff.

\section{UCA Collapses around the World}

In the following paragraphs, we describe the most recent UCA collapses on the world, with a special focus in Latin America. The purpose of this is not to describe in a very detailed way every one of the incidents, but to mention the most relevant, center the attention in the damages these events cause in society and expose the permanent threat UCA represent to people. We make emphasis on the importance of constant surveillance and maintenance of these structures and propose an addition to an article of the National Water Law, that specifies the prohibition of new UCA construction over rivers an natural stream in Mexico. Nevertheless, before to describe the most recent UCA collapses on the world, shown the elements that make up an UCA are the following (Figure 1 and Figure 2): 1) Foundation; 2) Pier; 3) Water flow surface; 4) Clearspan; 5) Kidneys; 6) Voussoir; 7) Extrados; 8) Intrados; 9) Keystone y 10) Rise. [2] depicts a much more detailed description of other elements, however, the most relevant are the ones mentioned here.

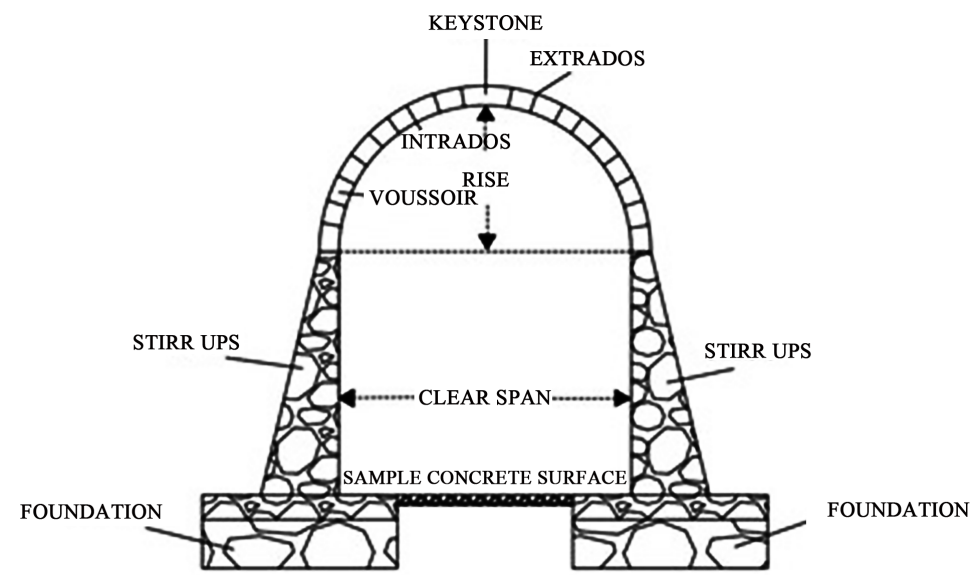

Figure 1. UCA's elements.

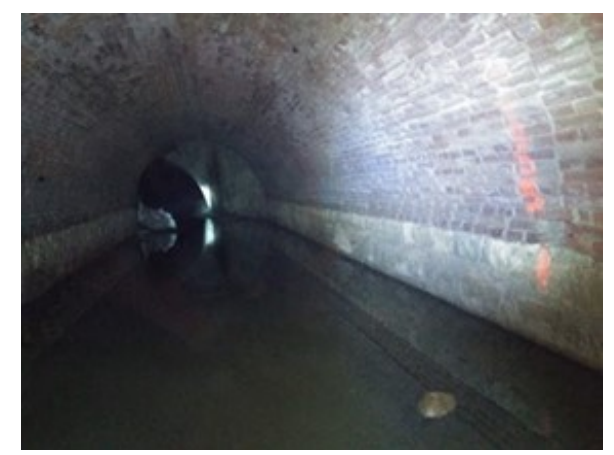

Figure 2. San Roque's UCA, Tuxtla Gutiérrez, Chiapas [3]. 
Fuengirola, Malaga, Spain. In the first week of February 2003, a torrential rain of 103 liters $/ \mathrm{m}^{2}$ fell on Fuengirola, Malaga. The rain lasted only two hours, but it provoked floodings in the Mijas municipality, broke highways and caused the collapse of a UCA in the Los Pacos area [4]. In the same city but during the rainy season of 2004, the intense rain affected about 1000 houses, and the strong currents caused by the floods dragged 700 cars. The Public Works Department banned future constructions of UCA on rivers in Spain due to the risks they represent to the population.

Quito, Ecuador. On March 31 in 2008, a sinkhole of approximately 250,000 m formed in the road distributor El Trebol in the city of Quito, due to a UCA collapse. The sinking created a 30-meter wide and 40-meter deep crater (which grew to a 120-meter diameter due to winter rains and runoffs). The sinkhole was formed by the UCA collapse located 30 meters under the highway of the El Trebol. The UCA was built to channel the Machangara river which runs under the Trebol [5]. According to [5], the UCA collapsed because it was designed to operate as open channel hydraulic, however, due to the excess water flow from the rains on March 31st, it worked as a pipeline. People close to the site reported that the river's level was $2 \mathrm{~m}$ above the UCA key. The Manchaga river usually has a $170 \mathrm{~m}^{3} / \mathrm{s}$ flow so, even though we don't know the maximum water flow of the river during that day, it's a fact that the UCA capacity was greatly exceeded. The water flow force combined with sediments, big sized rocks, trash, and wood pieces damaged the structure to the point of destruction, which led to its collapse [5].

Mexicali, Baja California, Mexico. In December 2014, The Rio Nuevo's UCA in Mexicali, Baja California, collapsed. A structural failure caused the UCA to cave in close to the Independencia Avenue junction. The UCA had a geometric section of $20 \mathrm{~m}^{2}$ [6]. Fortunately, no lives were lost, but the economic problems plus the potential danger of a collapsed structure near an inhabited area alerted authorities.

Toluca, Estado de Mexico, Mexico. Toluca is the capital of the Estado de Mexico, and the city has grown in a disorganized way with hundreds of people living in federal areas of the rivers that cross the city. According to the Water and Sanitation Organism of Toluca, families are at risk for the possible collapse of the UCA constructed above Verdiguel River (Figure 3). The federal area of the Verdiguel channel was invaded by citizens who built their houses over the UCA, and the risk grows every day due to the erosion of the structure's foundation, especially on the stretch between Morelos Street and Maestros avenue. Citizens and some concerned institutions have reported the situation to the authorities because there is a record of previous minor collapses of the structure. On February 10, 2015, a part of it caved in between the Lerdo and Quintana Roo streets [7].

Ambato, Ecuador. The UCA "El Tumbe" located in Cayambe, Pichincha, province of Ambato, is a $2 \mathrm{~km}$ long brick structure that crosses the city from north to south. The UCA was constructed underneath medium-rise buildings, 


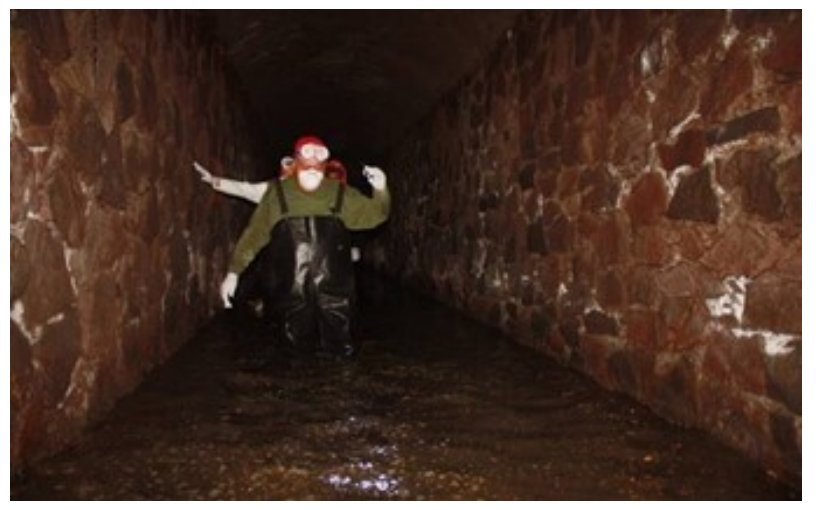

Figure 3. Verdiguel river's UCA [7].

family homes and communication routes in which light and heavy vehicles transit [8]. Years ago, a section of the UCA collapsed and caused the death of a person who had built their house over the structure, so the city ordered an investigation to determine the state of the UCA, and concluded that the risk of collapse is high. Into the UCA circulates wastewater and is constantly exposed to humidity, methane, sulfur and several gas emissions, which accelerate the deterioration of the structure [8].

Caranavi, Bolivia. Caranavi is a province that belongs to the La Paz department, and its located $161 \mathrm{~km}$ away from the country's capital, between the foothills of the Cordillera Real and the lowlands of the Bolivian Amazon forest. Caranavi's principal economic activity is agriculture, and the province is known as the coffee capital of Bolivia. It has more than 50,000 residents and it's one of the most productive provinces of the department. The city is located in a valley between two hills where the Ichilo river flows, and the rough topography that surrounds the city allows heavy runoff to flow at great speed inside the UCA, especially when extreme hydrometeorological events occur. The water current transports stones, tree branches, mud, and trash which erode and cause sinkholes in the structure's foundation, increasing its risk of collapse. On March 3rd, 2016, the UCA in Caranavi caved, an event that generated a landslide and the eventual destruction of 11 houses [9]. Bolivia is the country with the highest UCA collapses rates in Latin America.

Granada, Spain. In the XIX century, Granada started building the Gran Via, which led to constructing the UCA in the Darro river. During the XIX and XX centuries, the intense rains that hit the city increased the river flow, which resulted in several dangerous incidents. The most notable are the following: on July 21st, 1839, the rainstorms provoked a great runoff that collapsed the Darro's UCA, in the Puerta Real section. Forty-five years later, on March 14 and 15, 1887, the strength of the water flow broke down the UCA from Puerta Real down to Humilladero. Sixty-four years after that, on the 12th of September, 1951, the UCA collapsed again in the Puerta Real area [10], due to intense rains. On that occasion, the Darro river flooded the Correos building area, which provoked the slip of the emblematical building. Recently, on August 23, 2018, the 
river overflowed, and the high-speed and force of the water currents generated sinkholes in the UCA structure, landslides, and the sinking of the Montecarlo Hotel's foundation in the heart of Granada.

La Paz, Bolivia. Bolivia's capital was built in one of the highest points over the sea level, on the Andes Altiplano plateau, and stands at 3,500 meters above mean sea level. It extends over to the El Alto city, close to the Illimani mountain that has an elevation of 6,438 mamsl. The rain season lasts from November to March, and La Paz has an average annual precipitation of $573 \mathrm{~mm}$ [11]. However, in the last five decades, a series of extreme hydrometeorological events have generated natural disasters and the loss of human lives. On February 19, 2012, a intense rain of $41 \mathrm{~mm}$ the lasted about 1 hour, provoked disaster in La Paz. This event that had no precedents on data base in the Meteorological and Hydraulic Service of Bolivia, goes well above the $39.655 \mathrm{~mm}$ of rain forecasted by the Alto station for a 3-hour rainfall that could occur once every 100 years [12]. The intense rains of January 13 in 2019, caused the river Sokeri's UCA to become clogged with debris, rubbish, and wood. The water force and the rubble dragged by the current caused the UCA to collapse. The incident happened after intense rain and a hailstorm that began around noon, and that lasted one hour. The overflowing waters also caused the fall of a wall and the flooding of the parking lot in the Cumorah building [13]. In the same city, but on February 16, 2019, the river Apumalla's UCA was collapsed due to the stones, tree trunks and trash that water dragged from the upper part of the drainage basin to said UCA, located on the Apumalla Avenue. The collapse damaged 5 houses [14].

Marbella, Spain. On March 2019, the political party Izquierda Unida (IU) requested to the Chamber of Deputies a technical report be evaluated and made on the state of the UCA structure of the Arroyo Primero river, from the La Serranía to Severo Ochoa. The IU petitioned the assessment of the physical state of the structure to prevent further damage and future collapse [15]. According to the IU, the UCA was built in the 1990 decade, but ever since its construction the La Torrecilla, Serraní, and Lomas Bellas urbanizations have had flood problems, which affects more than 2000 people.

Zacatecas, Mexico. Each rainy season, the risk of collapse of the UCA in the historic center of Zacatecas resurfaces due to the undermining, erosion, and lack of maintenance of its structure. Some of the damaged sections are close to cavities in the subsoil, product of the mining activities of the XIX century, which have weakened the structure's foundation [16]. In the wake of the collapse of a section of the UCA, the Public Works Department (PWD) intervened to repair the damage and in 2014 the Protection Board for Monuments and Typical Areas elaborated a diagnosis of the physical state of the UCA, intending to study the structure's stability. The UCA was built in several stages from 1850 to 1900 approximately, during the colonial era [17].

In April 2019, the Department of Environment and Water (DEW) delivered another study that confirmed the need to give constant upkeep to the UCA (Figure 4). The DEW studied about 200 hectares of the principal UCA and 


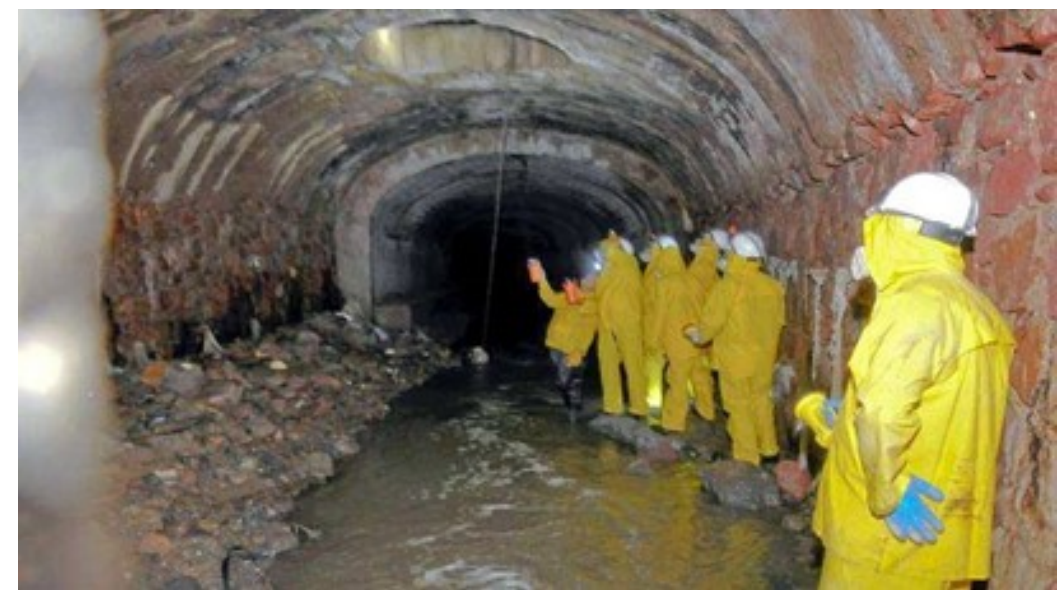

Figure 4. La Plata river's UCA, Zacatecas, Mexico [16].

seven secondary ones located in the area. The UCA begins in Bracho hills, goes all the way to Bicentenario Square, and continues in direction to the Guadalupe municipality. There, the UCA branches into secondary channels, which have also suffered several collapses. In the city's historic center, which was declared Cultural Heritage of Humanity, are several important buildings like the Government's Palace and the Cathedral which are among the hundreds of constructions built over the UCA, and are in danger due to the natural deterioration and lack of maintenance of the structure [16].

Table 1 shows a resume to UCA's collapsed of various cities around the world.

\section{The UCA and the National Water Law in Mexico}

The UCA and the NWL. Despite their importance, UCA is not mentioned in any of the NWL articles or sections. The National Water Law discusses big, medium and small hydraulic works like dams, wastewater treatment plants, storage basins, potable water systems, dikes, aqueducts, channels, wells, drains, flood barriers and ditches, but says nothing about UCA. The UCA should be mentioned in the NWL article 3, in order to enunciate its definition and its constitutive elements. The UCA have great importance today not only for their hydraulic function but also for its design, constructive process and maintenance methods. They become even more relevant when we consider that, in Mexico, hundreds of kilometers of UCA exist across the country with thousands of families living over them or close by. The lack of maintenance of these structures represents a high risk to the population's safety because it could be damaged to the point of collapse, and their vulnerability becomes more clear when intense rains or extreme meteorological events occur. The immense majority of UCA built in Mexico are located in urban areas of the country, where thousands of people live today, above or next to them.

The UCA and the federal area. The UCA and the federal area. Article 3 of fraction XLVII of the National Water Law describes Mexico's federal area of rivers and streams the following way: “... Banks or Federal Area: The 10-meter 
Table 1. The UCA's collapse.

\begin{tabular}{|c|c|c|c|}
\hline Hydrometeorology event & City & Year & Damages \\
\hline Torrential rain & Fuengirola, Spain & 2003 & Flood in the Mijas municipality and collapse of Pacos's UCA \\
\hline Intense rain & Fuengirola, Spain & 2004 & 1000 houses affected. The flood dragged 700 cars. \\
\hline $\begin{array}{c}\text { Torrential rain and } \\
\text { Manchágara River floods }\end{array}$ & Quito, Ecuador & 2008 & $\begin{array}{l}\text { Collapsed Manchágara's UCA and collapsed a piece the road distributor } \\
\text { named "El Trebol" }\end{array}$ \\
\hline Structural failure & Ambato, Ecuador & 2014 & $\begin{array}{l}\text { A section of the UCA collapsed and caused the death of a person who } \\
\text { had built their house over it. }\end{array}$ \\
\hline $\begin{array}{l}\text { Structural damages from } \\
\text { erosion and sinkholes }\end{array}$ & Zacatecas, México & 2014 & $\begin{array}{l}\text { In the city's historic center there are several important buildings like } \\
\text { the Government's Palace and the Cathedral which are among the } \\
\text { hundreds of constructions built over the UCA. }\end{array}$ \\
\hline Intense rain & Toluca, México State & 2015 & $\begin{array}{l}\text { A part Lerdo's UCA collapsed (hundreds of people living in the federal } \\
\text { areas of the river are at high risk). }\end{array}$ \\
\hline Torrential rain & Caranavi, Bolivia & 2016 & A part of Caranavi's UCA collapsed and the eventual destruction of 11 houses. \\
\hline Torrential rain & $\begin{array}{l}\text { Tuxtla Gutiérrez, } \\
\text { Chiapas, México }\end{array}$ & 2016 & $\begin{array}{l}\text { An apart of the San Roque's UCA collapsed and six houses were damaged. } \\
\text { Collapsed a house over the San Roque's UCA too. }\end{array}$ \\
\hline Torrential rain & Granada, Spain & 2018 & $\begin{array}{l}\text { The Darro river flooded the Correos building area, which provoked the } \\
\text { slip of the emblematical building and generated erosion and sinkholes } \\
\text { in the Darro's UCA. }\end{array}$ \\
\hline Torrential rain & Las Paz, Bolivia & 2019 & $\begin{array}{l}\text { Collapsed Sokeri's UCA. The overflowing waters also caused the fall of } \\
\text { a wall and the flooding of the parking lot in the Cumorah building. }\end{array}$ \\
\hline
\end{tabular}

strip next to the channel measured horizontally from the maximum ordinary water level. In a 5 meter wide channel, the bank amplitude must be 5-meters long and the ordinary maximum level will be determined by 'The Commission' or by the corresponding Basin Organism, in line to their respective competences and according to the regulations addressed in this law. In channels with a maximum 5-meter width, the maximum ordinary level will be calculated from the average maximum annual flow water of 10 consecutive years. In rivers, these strips will be delimited from 100 meters upstream, beginning in the river mouth to the ocean. In the origin of any stream is considered as channel when the runoff that concentrates on a topographic depression forms a channel on the ground as a result of the water flow over the terrain. The channel must be at least 2-meter wide and 0.75 meters deep."

The ninth title, article 113, Fraction III, of the National Water Law affirms that Mexico's federal areas are national property, including river banks, the land alongside a body of water (Fraction IV). Construction in federal areas requires a permit issued by The National Water Commission (CONAGUA in its Spanish acronym). The Federation's Official Diary published the National Water Law for the first time on December 1st, 1992, so many of the UCA, even the ones built after the publishment of the law, don't have the construction licenses required. 
For this reason, all existing UCA in Mexico must be registered (with the actual requirements that CONAGUA demands today) to regularize them as the NWL indicates. With this initiative, we could create a national data bank with the following information (users of the federal areas): name and address of the applicant, location of the federal terrain and adjoining land lots, land's surface area, duration of the solicitation, objective of construction (or exploitation), land use, technical reports, environmental impact study or exemption of it (according to article 5 of the General Ecologic Equilibrium and Environmental Protection Law).

The NWL, floods, and human life protection. The National Water Law is derived from Article 27 of the Political Constitution of the United States of Mexico and it regulates all matters related to national waters in Mexican territory, and its dispositions are of public order and social interest. Its objective is to control the exploitation, distribution of said waters, and the preservation of its quantity and quality to achieve sustainable development [18]. The law, in its second article, establishes that its dispositions apply to all national waters, whether they are above or underground.

In chapter V, Article 83 of the NWL (That mentions control and protection against floods) affirms: “... The Commission, through the Basin Organisms, in coordination with the municipal and state governments or with physical and moral people, must build and operate the hydraulics works, in order to protect the flooding areas, as well as roads and complementary works that make possible the best use of land and protection of population centers, industries, human lives, and their properties, according to Title Eight dispositions. The Commission, in terms of the regulation and with the support of the Basin Organisms, will classify areas according to their possible flood risk, will emit the necessary norms and recommendations, will establish the operation, control and follow up measures and will apply the contingency funds integrated to the purpose. However, in practice, Article 83 only applies to large channels and rivers of Mexico, where CONAGUA and the Federal Electricity Commission (CFE in its Spanish acronym) built and operate big hydraulic structures like dams, and it doesn't apply to the majority of basins, sub-basins, and micro-basins in Mexico where minor hydraulic works are located".

For this reason, municipalities need to classify their territories according to their flood risk, to protect human lives and their personal properties. Today, cities and towns with UCA do not have a contingency or civil protection plans in case of disaster, or even plans for constant maintenance for the structures. This is an important matter that falls under the federation's jurisdiction, it must be also contemplated by Mexico's states and municipalities but the federation is responsible because the UCA are built on federal soil of streams and rivers in Mexico.

Thus, four UCA located in Tuxtla Gutierrez, Chiapas, present the same circumstances described above. All were built over the Sabinal sub-basin, and the oldest one is more than 50 years old. The institutions responsible for their 
maintenance (municipality, state, and federation) have failed to take action and haven't emitted the necessary norms and recommendations, or stablished control measures and follow up plans in case of disasters, as the law indicates. They have also ignored the National Water Law's legal determinations and its dispositions despite that, in 2016, several houses built over the San Roque UCA suffered great damage following a rainstorm, and one collapsed after the vault caved in. In the San Roque UCA there is a 1200-meter long stripe in the city, where the tunnel vault runs underneath medium-rise buildings, family homes and communication routes in which light and heavy vehicles transit, that we consider a high-risk area (https://www.youtube.com/watch?v=2PKq8NiaR1Q), from the 7th East and 2nd North streets to the 10th South and 3rd East streets.

On September 2, 2016, a section of the San Roque UCA, located at 12th South and 3rd East street in Tuxtla Gutierrez, Chiapas, collapsed. That night, the rains lasted three hours with a $115 \mathrm{l} / \mathrm{m}^{2}$ intensity, the out of control runoff overflowed the stream and damaged houses close to it and the water flow dragged a vehicle. Photo 3 shows the collapsed tunnel vault. The lack of maintenance and insufficient capacity of UCA, plus the hydraulic push and the flow's momentum caused the UCA to break and collapse, taking down a house built over it, and damaging six more houses (Figure 5).

For these reasons and for the first time multidisciplinary group of diverse experts from the Engineering Faculty of Chiapas State University (UNACH by its acronym in Spanish) and the Civil Engineer Association of Chiapas (CICCH by its acronym in Spanish), with the support of the Municipal Civil Protection, entered the San Roque UCA to verify its physical state. The team, made of specialists in hydraulics, hydrology, civil structures, materials science, corrosion, and topography, conducted a study focusing on the hydraulic and structural problems of the tunnel vault, the corrosion, and erosion undercuts it presented in its structure. The results were published in [3] [20], and also I suggest seeing the following links:

https://www.youtube.com/watch?v=MkXuOTc_VkI\&t=235s;

https://www.youtube.com/watch?v=2PKq8NiaR1Q.

The UCA and the riverbanks disappearance. The National Water Law must prohibit the construction of UCA in rivers, and this work presents the technical arguments to support this. The NWL must do it explicitly, in article 100, that

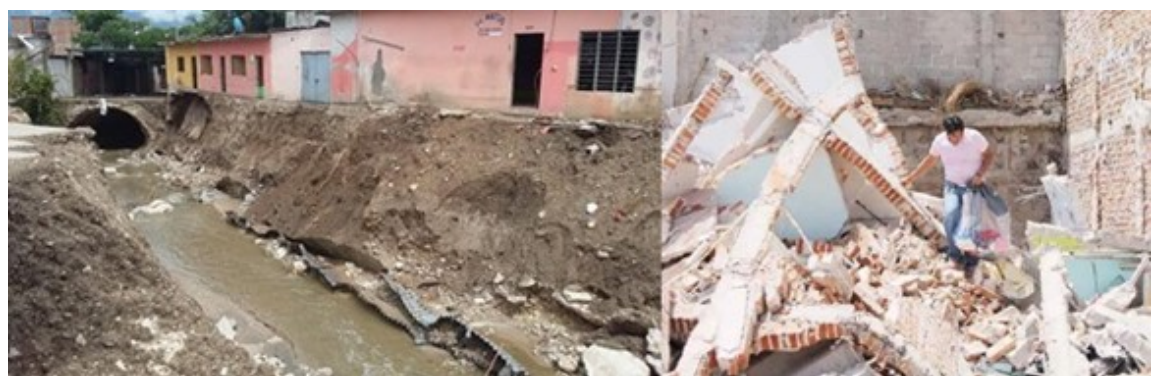

Figure 5. UCA and house, collapsed [19]. 
today reads: "... The Commission will set up the norms or take the necessary actions to avoid the construction or operation of a structure that alters unfavorably the hydraulic conditions of a stream, because endangers the lives of citizens, their properties or the vital ecosystems". Another reason to avoid the construction of these structures in rivers and streams of the nation is exposed in the following: The UCA eliminates or at least interrupts, the natural stream beds which are the transition between land and aquatic habitats. This strips of land fulfill an ample range of purposes, for example, 1) They help maintain the hydrological and hydraulic regime of stream beds; 2) They provide stability to the soil at the river's edges; 3 ) They regulate the water flow to avoid floods; 4) They keep a base water flow; 5) They protect aquatic ecosystems from contamination; 6) They catch and filter sediments, nutrients, and chemicals; 7) They protect diverse fish species and Sylvester life, providing food and shelter [21]. The UCA not only restrict the hydrological capacity of rivers and streams but also, when they collapse they severely damage the infrastructure, public and private properties and put people's lives at risk. For this reason, we propose an addition to article 100 of the National Water Law, fraction 1, which empowers said article under the following normative assumption:

The construction of UCA over perennial or non perennial natural stream flows, is strictly prohibited in order to protect animal and plant life of their banks and protect their natural runoff.

\section{Causes for Tunnel Vault Collapse}

Multiple situations can cause a UCA collapse, but the most relevant are earthquakes, undercuts, and floods.

Earthquakes. When a UCA is not designed to support certain ranges of seismic accelerations, or when it's been miscalculated, structural failures which can lead to its collapse.

Soil mechanics (sinkings). In a river bed, the water table will always be high. Soils with large levels of humidity usually deform under pressure, which generates collapse risk on a UCA, especially in those cases where the soil was not "reinforced", or those with the foundation built over soft ground. According to field studies and numerical simulation models elaborated by [22], the tunnels constructed on saturated soils show that the distortion of the surrounding ground occurs mainly when the excavation is not deep, for example, between 2.0 and 0.5 of the UCA diameter. Thus, the structure will be more prone to collapse when the lithological conditions are not good enough and the soil's resistance diminishes because of water infiltration [22].

Floods. Of the events mentioned before, this one is the most relevant of them. The highest percentage of UCA collapses in the world is caused by floods, which are phenomenons that cause economic damages and loss of lives (World Bank 2011). According to the Inter American [23], Central Latin America is the most vulnerable region to natural disasters and has the highest average cost of economic losses. Unfortunately, in Latin America and the Caribbean, each natural 
disaster event represents a loss of $0.18 \%$ of their GDP [24] where floods are most frequent. Floods are the most common disasters that occurred in Central Latin America between 1970 and 2013, and one of the major vulnerabilities of the cities of Latin America is pluvial plumbing. Among all-natural disasters that occurred in ALC between 1970 and 2013, floods occupy the first place (Fernandez et al. 2016) and one of their major vulnerabilities is drainage pluvial.

\section{Conclusion}

The construction of new UCA must be prohibited in Mexico by the National Water Law because when they collapse, they severely damage the city's infrastructure and cause loss of human lives. After the analysis of various UCA collapses in different cities of the world, it can be seen that Latin America is one of the most affected areas. On the other hand, it can be seen that in the Mexican Republic have happened several UCA collapses, especially when extreme meteorological events happen. Data shows that, unfortunately, this kind of aleatory events will continue to happen because thousands of rivers and streams in Mexico have been tubed or construct UCA over them. The care and maintenance for those structures have been neglected by the competent authorities. Some of those structures are more than 150 years old as the UCA over La Plata stream in Zacatecas. Others, like the 50-year-old San Roque UCA in Tuxtla Gutierrez, also lack contingency plans, norms, and recommendations for disaster monitoring and control, as the law requires. The San Roque UCA, and the rest of UCA built in the Sabinal sub-basin must be under permanent supervision and preservation by specialized technicians. Otherwise, disastrous events like the one on September 2, 2016, will continue happening. In Mexico, the construction of UCA over natural rivers or stream must be banned, and the institutions responsible for the existing ones must be obliged to give constant supervision, maintenance and repairment. Finally, in this document is proposed an addition to the section I, article 100 of the National Water Law that announces: The construction of UCA over perennial or non perennial natural stream flows, is strictly prohibited in order to protect animal and plant life of their banks and protect their natural runoff.

\section{Acknowledgements}

I appreciate the translation made by Arch. Laura Montserrat Mundo Navarro, who has executed an impeccable work.

\section{Conflicts of Interest}

The authors declare no conflicts of interest regarding the publication of this paper.

\section{References}

[1] Huerta, F.S. (2004) Arcos, bóvedas y cúpulas. Escuela Técnica Superior de Arqui- 
tectura. Instituto Juan de Herrera, Madrid.

[2] Gutiérrez, M. (2008) Teoría y diseño de una bóveda. Escuela de Ingeniería Civil de la Universidad del Salvador, San Salvador.

[3] Mundo, M.M. (2019) Determinación del estado hidráulico de los embovedados del arroyo San Roque. Centro de Investigación de la Facultad de Ingeniería. Informe técnico final. Universidad Autónoma de Chiapas, Tuxtla Gutiérrez, Chiapas.

[4] Agencias Málaga (2003) Una tromba de 103 litros en 2 horas colapsa Fuengirola. Málaga.

https://www.diariocordoba.com/noticias/sociedad/tromba-103-litros-2-horas-colap sa-fuengirola_40227.html

[5] Arias, J.N. (2008) Hundimiento el Trébol, respuesta a la emergencia. Instituto de Altos Estudios Nacionales, Informe técnico, Quito.

[6] Arellano, S.L. (2014) Por fallas estructurales colapso tramo de embovedado del Río Nuevo. Mexicali, Baja.

http://www.unimexicali.com/noticias/mexicali/310658/por-fallas-estructurales-cola pso-tramo-de-embovedado-del-rio-nuevo.html

[7] El Sol de Toluca (2018) En riesgo 35 mil personas ante posible colapso de la bóveda del Río Verdiguel.

https://www.elsoldetoluca.com.mx/local/en-riesgo-35-mil-personas-ante-posible-co lapso-de-la-boveda-del-rio-verdiguel-2856566.html

[8] Cayambé, G.J. (2015) Análisis estructural del embovedado del colector sanitario El Tumbe ante el riesgo de colapso en el cantón Cayambé, Provincia de Pichincha. Tesis de licenciatura, Facultad de Ingeniería Civil y Mecánica, Universidad Técnica de Ambato, Pichincha, Ambato.

[9] BETM (2016) Las lluvias dañan viviendas y caminos en Caranavi, La Paz. https://www.boliviaentusmanos.com/noticias/bolivia/193670/las-lluvias-danan-vivi endas-y-caminos-en-caranavi-la-paz.html

[10] Mingorance, L. (2018) El incidente rescata al río Darro del olvido. https://www.granadahoy.com/granada/incidente-rescata-rio-Darro-olvido_0_12760 72646.html

[11] Quispe, M.J. (2018) Curvas IDF para la estación meteorológica de Viacha, departamento de La Paz. Revista de Investigación e Innovación Agropecuaria y de Recursos Naturales, 5, 99-105.

[12] Maldonado, N.R. (2015) Determinación de relaciones intensidad-duración-frecuencia (IDF) de 11 estaciones meteorológicas del altiplano, mediante el análisis de eventos extremos de precipitación. Tesis de Maestría, Facultad de Agronomía de la Universidad Mayor de San Andrés, La Paz.

[13] La razón (2019) El colapso de una bóveda daña cinco coches en un edificio de Miraflores. La Paz, Bolivia.

https://www.boliviaentusmanos.com/noticias/bolivia/193670/las-lluvias-danan-vivi endas-y-caminos-en-caranavi-la-paz.html

[14] Urgentebo (2019) El río Apumalla colapsó debido a la acumulación de basura y escombros. La Paz, Bolivia.

https://www.urgentebo.com/noticia/el-r\%C3\%ADo-apumalla-colaps\%C3\%B3-debi do-la-acumulaci\%C3\%B3n-de-basura-y-escombros

[15] Marbella Confidencial (2019) IU pedirá al Pleno que se actúe ante el riesgo de inundaciones en el entorno de La Cañada.

http://www.marbellaconfidencial.es/iu-pedira-al-pleno-que-se-actue-ante-el-riesgode-inundaciones-en-el-entorno-de-la-canada-431758238 
[16] El Sol de Zacatecas (2019) Con la lluvia, aumenta peligro de colapso de antigua bóveda en Zacatecas.

https://www.elsoldezacatecas.com.mx/local/con-la-lluvia-aumenta-peligro-de-colap so-de-antigua-boveda-en-el-centro-historico-de-zacatecas-3807783.html

[17] González, R.M. (2017) Puentes, tiros de mina y arroyos embovedados, bajo el Centro Histórico de Zacatecas.

https://www.periodicomirador.com/2017/11/30/puentes-tiros-mina-arroyos-embov edados-centro-historico-zacatecas

[18] DOF (2016) Ley de Aguas Nacionales. Diario Oficial de la Federación (DOF) Ciudad de México, México.

[19] Alvarado, M.A. (2016) Afectados en San Roque temen que los dejen solos. Tuxtla Gutiérrez, Chiapas.

https://www.nvinoticias.com/nota/32684/afectados-en-san-roque-temen-que-los-de jen-solos

[20] Pérez, D.J.L., Godínez, D.E., Mundo, M.M. and Hernández, C.D. (2019) Inspección por corrosión y estructural del embovedado San Roque de Tuxtla Gutiérrez, Chiapas. Espacio I+D Innovación más Desarrollo.

[21] Peñaloza, R.X. and González, V.J. (2015) Delimitación de riberas de ríos y arroyos. Instituto Mexicano de Tecnología del Agua, Jiutepec.

[22] Liu, N.F., Li, N., Li, G.F., Zhang, Z.Q. and Mu, Y.H. (2018) Deformation and Collapse Mechanisms of Water-Rich Soil Tunnels. Soil Mechanics and Foundation Engineering, 54, 384-394. https://doi.org/10.1007/s11204-018-9485-5

[23] World Bank (2011) Cities and Flooding: A Guide to Integrated Urban Flood Management for the 21st Century. The Worl Bank, Washington DC.

[24] Fernández, I.C. and Buss, S. (2016) Ocurrencia y Gestión de inundaciones en América Latina y el Caribe-Factores claves y experiencia adquirida. División de Agua y Saneamiento, Banco Interamericano de Desarrollo. 